\title{
Regulation of Halal and Healthy Products for Small-scaled Businesses as Consumer Protection
}

\author{
Neneng Uswatun Khasanah ${ }^{1}$, Martha Eri Safira ${ }^{2}$, Winantu Kurnianingtyas Sri Agung ${ }^{3}$ iD, Mochammad Chotib ${ }^{4 *}$, \\ Setiawan Bin Lahuri ${ }^{5}$, Elok Putri Nimasari ${ }^{6}$ \\ ${ }^{1}$ UNIDA Ponorogo, Ponorogo, Indonesia; ${ }^{2}$ IAIN Ponorogo, Ponorogo, Indonesia; ${ }^{3}$ Department of English Education, IAIN \\ Ponorogo, Ponorogo, Indonesia; ${ }^{4}$ IAIN Jember, Jember, Indonesia; ${ }^{5}$ UNIDA Ponorogo, Ponorogo, Indonesia; ${ }^{6}$ Universitas \\ Muhammadiyah Ponorogo, Ponorogo, Indonesia
}

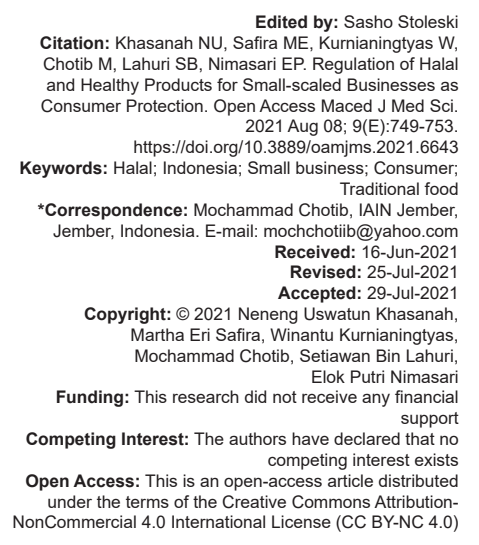

\begin{abstract}
AIM: The purpose of the study was to know the regulation on halal and health guarantee of Indonesian snacks such as cilok (tapioca balls), grilled meatballs, meatball and chicken noodles, dawet drink (traditional drink from rice flour and coconut milk), crackers, and grass jelly drink. Such snacks and drinks are loved by all levels of society in Indonesia and are often sold by street vendors in various places.

METHOD: This research uses a juridical-sociological approach, by analyzing the primary source of data, which is by directly observing, interviewing, and educating the society and the small-scale sellers on the important sense of the halal product and the halal product certification. Apart from that, the primary data are the Law No. 8 of 1999 on the Consumer Protection, the Law No. 33 of 2014 on the Halal Product Guarantee, and the Governmental Decree No. 31 of 2019 on the Halal Product Certification.

RESULTS: The realization of consumer protection requires good coordination between the government and/or regional governments, business actors, and the community as consumers. The need for halal and healthy products is not only for Muslim communities but also for non-Muslim communities, because halal products are certainly guaranteed of the products' hygiene and safety.

CONCLUSION: There is still a lack of understanding and compliance by the small business owners on the halal and healthy products from the manufacturing process up to the distribution of the products to the public.
\end{abstract}

\section{Introduction}

Indonesian small businesses which sell cilok (tapioca balls), meatballs, chicken noodles, sempolan, es cincau (grass jelly drink), dawet drink (traditional drink from rice flour and coconut milk), etc., are businesses which require small capital, which receive a relatively plenteous and stable profit, carried out by small-scale sellers or street vendors. Almost all levels of the society like these snacks and drinks.

Unfortunately, there are profit-oriented business actors who ignore consumer safety. There are business owners who have a legal license of their businesses, but many still don't. Because of that, there needs to be a special attention from the government, in guiding, monitoring, and encouraging small business actors to have business legality and to produce their products safely according to the constitutional regulations which apply.

The people of East Java Province enjoy snacks and there is the tradition of enjoying angringan (a place which sells a variety of traditional foods and drinks), where all snacks and drinks are available. Many of the snacks and drinks sold in Ponorogo, Madiun, Surabaya, and Jember do not fulfill the health standard in their production process, hygiene, nutrition, composition, the method of sales, and the method of packaging (personal communication to street vendors in Ponorogo and Jember, August 12-18, 2019).

Results of the research show that many of the snack and drink vendors in front of schools, in city centers, in city parks, and in markets in East Java do not pay attention to the health and the quality of the products that they sell (personal communication to street vendors in Ponorogo and Jember, August 12-18, 2019). The issuing of the Law No. 8 of 1999 on Consumer Protection and also the sanctions in it do not make the snack and drink sellers increase the quality of their products. Apart from that, this is also influenced by the weak supervision of the government, which makes it as if they are kings.

The issuing of the Law No. 33 of 2014 on the Halal Product Guarantee becomes good news for the people as consumers to enjoy the food, drinks, medicine, and also cosmetics with guaranteed health, 
safety, and quality. To make sure that that law is enforced well; thus on 2019, the government issued the Governmental Decree No. 31 of 2019 on the Halal Product Certification. Thus, the halal product guarantee is not only encouraged (mogen), but it becomes an obligation [1].

With the issuing of Law on the Halal Product Guarantee (LHPG) (hereinafter referred to as LHPG), it is an obligation for the production of foods, drinks, medicine, and cosmetics to have the halal label, especially as it is strengthened with the Governmental Decree No. 31 of 2019. According to the LHPG Article 1 point 10, it is explained that a business actor is an individual person or a business entity in the form of a legal entity or a non-legal entity which carries out business activities in the Indonesian territory. All business owners who produce a type of processed product (food, drinks, medicine, and cosmetics) must register their products to receive a halal certificate. Then, Article 4 of the LHPG stipulates that the products which enter, distributed, or sold in the Indonesian territory must have the halal certification.

Departing from that phenomenon, this article analyses on how the legal effectivity of the small business owners on the halal products is from the production process until the distribution of that product to the people. And the second one is, how is the legal enforcement of the halal product regulation on the small business owners so that they have halal certification and may produce or distribute their products in a halal manner.

\section{Methods}

This research uses the sociological-juridical approach [2], by examining the primary data sources. The researcher directly observes, interviews, and educates the people and the small sellers on the importance of the halal products and the halal product certification. Another primary data are the Law No. 8 of 1999 on the Consumer Protection, the Law No. 33 of 2014 on the Halal Product Guarantee, and the Governmental Decree No. 31 of 2019 on the Halal Product Certification. Inductive analysis is carried out on the collected data, which is analyzed using the analysis of the sociolegal studies.

\section{Results}

\section{The concept of legal effectivity}

Etymologically, the word effectivity comes from the word effective in English. In Dutch, it is called effectief, meaning "effective use" [3]. Linguistically, legal effectivity may be defined as the effective use of law, in this case regarding the success of the legal application itself [4]. Soekanto [5] states that among the factors which influence the degree of legal effectivity are the compliance of the people toward the law.

In the social studies, including the legal sociology, the problem of the legal compliance is the main factor in measuring the effectivity of the law [5]. Soekanto [6] states that legal effectivity is all efforts carried out so that the law in the society really lives. This means that the law is truly applied juridically, socially, and philosophically.

The people cannot live in an orderly manner without the law, as other norms cannot holistically fulfill the needs of the human beings on order and harmony [7]. Each group has the chance to influence each other and to fight for their values, their political aspirations, and other things which are according to them worth to be applied and to be complied with Budiono et al. [7]:

Rahardjo states that the enforcement of the law does not happen immediately as it needs some steps to apply [8]. Rahardjo also states that the main factor which influences the legal effectivity is the human beings, as the law is created and applied by people [8]. Even radically, Soekanto [5] states that to see if a regulation or a legal material functions or not, we can see whether that law is applied or not. About the application of a legal principle, Soekanto [5] states that for a legal principle or a regulation to function or to live in the lives of the people, that legal principle/law must fulfill these three elements:

1. The law must be applied juridically,

2. The law must be applied sociologically,

3. The law must be applied philosophically.

A law will function, work, and live in the society if in that law (materially or principally) may be applied juridically, sociologically, and philosophically (Figure 1). In the legal studies, it is known as the "Laws of Life." The Law of Life concept is as follows:

\section{The concept of consumer protection}

Consumer protection is an organized effort which in it contains the elements of honest and responsible government, consumers, and business owners in increasing the consumer rights. In LHPG, it is defined as all efforts which guarantee the legal certainty to give protection to the people toward their rights as consumers, with the following aims [9]:

a. To create a consumer protection system which contains access and information, and which guarantees legal certainty;

b. To increase the quality of goods and services;

c. To protect consumers against misleading business practices; 
d. To harmonize the regulations on consumer protection with other sectors.

LHPG is only aimed to protect both consumers and business actors. The issuing of the LHPG has the following aims [10]:

1. To maintain and to keep the certainty of quality, amount, and safety of the goods and services which are obtained from the market;

2. To increase the raise the consumers' awareness, knowledge, concern, capabilities, and independence so that they become more responsible.

Many things may bring loss to the consumers, including problems which regard the quality of the goods, the price of the goods, dishonest competition, forgery, fraud, misleading promotions, etc. Such things do not only bring loss to wealth or health, but they may also cause death, apart from causing consumption patterns which are improper to the consumers' income and education which is still relatively low.

\section{guarantee \\ The concept of halal and healthy product}

The definition of the halal product is regulated in the Law No. 33 of 2014 on the Guarantee of Halal Products on Article 1 point (2), which states that "Halal products are products which are stated as halal according to the Islamic sharia." For Muslim consumers, the consumption of food and drink products which are halal and which have guaranteed services is a must, except in conditions of emergency [11].

Islam gives a guide to the people to only consume products which are healthy and which have a halal guarantee. This applies to food products, drinks, food supplements, vaccines, medicine, cosmetics, etc. The halal guarantee is a fundamental thing for Muslim consumers. For the Muslims, the law is clear [11].

For Muslim consumers, the halal and health guarantee of products/services is crucial [12]. The consumption of halal products also gives guarantee of the safety and good quality, thus they may also be consumed by those who are not Muslims [13].

In the Law on Halal Product Guarantee, it is stated that all business actors, both which are public and private, both who are individual business actors or corporations, from those which have a legal entity and those which do not, have the obligation to have a certificate of halal guarantee.

This certificate will then be issued by the Halal Product Guarantee Governing Body (Badan Penyelenggara Jaminan Produk Halal/BPJPH). The issuer is the Halal Product Guarantee Governing Body. This is stated in Article 1 point (10) of the LHPG, which states that "The Halal Certificate is the acknowledgement that a product passes the halal standard, which is issued by the Halal Product Guarantee Governing Body based on a written halal fatwa issued by MUI." The implementing regulation is based on the Governmental Decree No. 31 of 2019.

Based on the Governmental Decree No. 31 of 2019 on the Halal Product Guarantee, all business actors' products which are distributed in Indonesia must have a halal guarantee by proposing an assessment to the authorized officials and must have a halal guarantee. On the one hand, for the Muslim consumers, the halal certification means that the products are according to the Islamic sharia, apart from the health, hygiene, and safety factors. On the other hand, for non-Muslim consumers, the halal certification represents a symbol of hygiene, quality, guarantee of health, purity, and safety [14].

\section{Legal effectivity of small-scale business actors on the halal products from the production to the distribution}

This research was carried out in some areas in East Java, including Ponorogo, Madiun, Jombang, Surabaya, and Jember, with the sample of around 50 small-scale sellers, or what is also called the street vendors. They offer various kinds of snacks and drinks which become the society's favorite, such as cilok (tapioca balls), bakso bakar (grilled meatballs), bakso mie ayam (meatball chicken noodles), sempolan (chicken sticks), es cendol (a drink from sugar palm, and rice flour, es cincau (grass jelly drink), etc.

The research results show that, regarding the production process, from the rinsing of the food materials, the usage of boiled water, the self-production of the food materials (making sure of the products' quality and hygiene), the usage of food coloring, the avoidance of artificial sweeteners, and the avoidance of preservatives and additives, it is shown that only $20 \%$ of the small-scale sellers, or only 10 out of 50 sellers pay attention to the product safety and the consumer safety. Only $30 \%$ of the small-scale sellers or 17 vendors sell the products well, use new packaging, rinse with clean running water, and cover the foods and drinks they sell well.

Then, regarding the legal understanding of the small-scale sellers, only $25 \%$ know, $25 \%$ understand, and $50 \%$ do not know. This means that 13 small-scale sellers know of the consumer protection. Thirteen sellers understand it, meanwhile, 24 do not know of the regulation on consumer protection.

Regarding the law on the halal and healthy product guarantee, and also the obligation on the halal product certification, it is an irony as all of the interviewed respondents are Muslims. The data obtained show that $60 \%$ of them do not know about the LHPG and the certification of the halal product but are interested. About $20 \%$ have heard of it. Then, the last $20 \%$ know 
of it but are not interested in practicing it, so long as people buy their products.

The results of interview to 100 respondents from the society or the consumers regarding the consumer protection and the halal product guarantee (Figure 2), which consisted of 50 housewives, employees, business owners; 25 college students; and 25 high school students may be seen in Tables 1 and 2 :

If reviewed from the concept of legal effectivity, it can be described philosophically, sociologically, and juridically regarding the legal factors, which are the Law on Consumer Protection, the LHPG, and the Governmental Decree on the Halal Product Certification, in the perspective of the small-scale sellers, these regulations are not yet understood and they do not know what to do with these regulations. Thus, philosophically, what is envisioned by these three regulations have not yet been ideally reached. Meanwhile, if seen from the sociological factor, the effectivity of those regulations in the society is not yet maximum. Regarding the juridical factor, the law enforcement of those three regulations is until now still very weak.

\section{Implementation of halal and healthy product regulations for small-scale business actors}

The halal industry has experienced a rapid development in several sectors, including halal food, finance, travel, fashion, healthcare, and education [15]. The term "industry" is defined as the activity in processing things using tools and equipment. Then, in the Indonesian context, the term "halal" means permitted by the Islamic sharia [16]. Thus, the halal industry may be defined as the activity in processing goods using the tools and equipment which is permitted by the Islamic sharia. For Muslim consumers, the halal and health (thayyib) guarantee of a product/service is crucial [12]. The halal status guarantees the safety of the product.

In article 8 clause (1) letter $\mathrm{h}$ of the Law on Consumer Protection, it is stated that the business actors are prohibited from producing and/or distributing goods and/or services which do not fulfill the stipulations on halal production. The government issued the LHPG as a form of Consumer Protection, especially for the Muslim consumers [17]. Then, for business actors, the issuing of the LHPG gives a guide on how to process, produce, and market their products to the consumers, and how to make an information on halal products to the consumers Apart from that, the producers also obtain benefits from this Law, which is the presence of a legal certainty toward all produced goods. Thus, the LHPG will give a positive impact to the business sector [18].

To accelerate the halal industry in the nation, the government at last issued the Governmental Decree No. 2019 on the Implementation Regulation of the Law No. 33 of 2014. The presence of this Governmental Decree strengthens the position of Indonesia as a producer of halal products. Considering that from October 17, 2019, all products must have the halal certification, including food, medicine, and other consumption goods [19].

Table 1: The society's response on halal-labeled products

\begin{tabular}{lll}
\hline No. & $\%$ & Sense of importance \\
\hline 1 & 80 & Very important \\
2 & 8 & Rather important \\
3 & 4 & Not very important \\
4 & 8 & Not important \\
\hline & This does not only apply & to higher-up
\end{tabular}
producers or business actors, but it also applies to the small-scale sellers or business actors who sell snacks and drinks on the roadsides. They must also have halal product certification. But, how all sellers and producers - wide scale, middle scale, or small-scale sellers - in producing food and drinks, have halal product guarantee certification decrees may be achieved? [20].

Nowadays, Millennials are more aware on the importance of healthy living, thus the good (tayyib) and halal food and drinks become the standard of choice [21].

Referring to the context of the regulation and the policies on economic development, it cannot be denied that nowadays in Indonesia, there is the popularity of the halal and healthy-based industry. This means that all business owners must understand the halal standard including the obligation of the halal certificate.

Table 2: The society's concern on halal label as consumer protection

\begin{tabular}{lll}
\hline No. & $\%$ & Concern \\
\hline 1 & 43 & Very concerned \\
2 & 34 & Rather concerned \\
3 & 14 & Not really concerned \\
4 & 9 & Not concerned \\
\hline
\end{tabular}

\section{Discussion}

The consumption of halal, healthy, and safe foods and products is a basic right of all human beings. This does not only regard a religious belief but it also

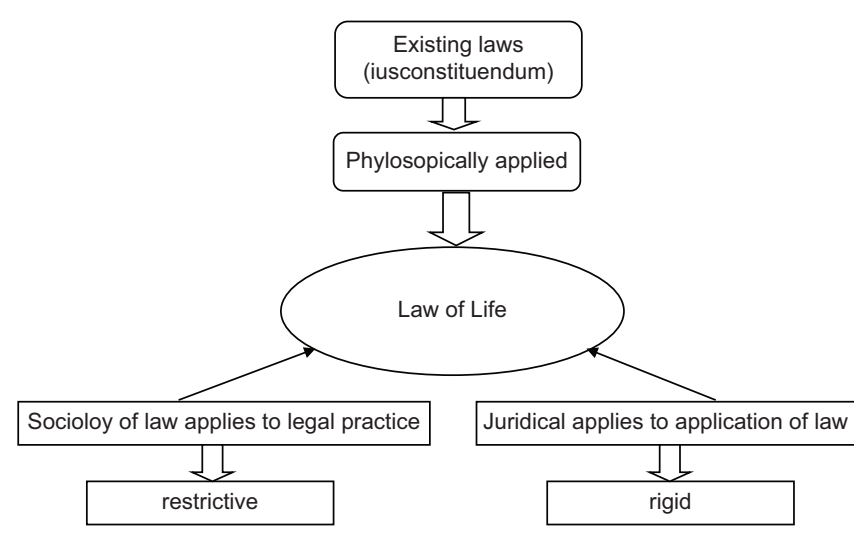

Figure 1: The law of life scheme 


\section{Halal Product Guarantee Governing Body}

- Mandate of the Law No. 33 of 2014 on Halal Product Guarantee - Has mandate to issue halal certificates

- Takes over the certification role of the Indonesian Islamic Scholar Assembly

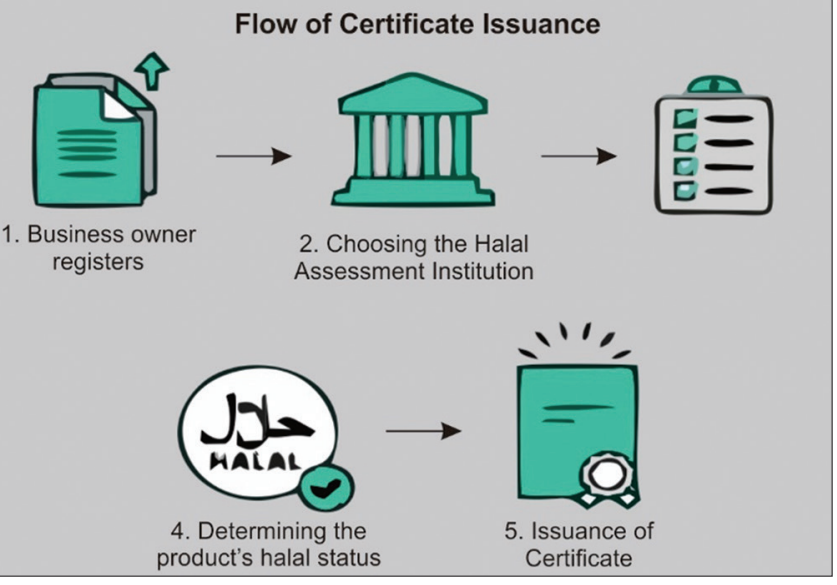

Figure 2: Halal certificate issuance process

regards the dimensions of health, economy, and safety which is maintained and guaranteed. Parallel to that, the higher-up, middle, and small-scale sellers, business owners, and producers must give protection to the consumers, as regulated in the Law No. 8 of 1999 on Consumer Protection [22].

Because of that, the issuing of the Governmental Decree No. 31 of 2019 shows that the halal certification becomes an obligation and having the halal product certification, the products will have various competitive advantages, especially to attract the Muslim community in many countries.

\section{Conclusion}

The halal certificate becomes crucial for Muslim or non-Muslim consumers as it regards the religious principle and the consumer rights, also it gives a sense of safety and guarantee in the health sector. The LHPG has not yet complied by small-scale sellers significantly, as most have not registered their products to obtain the halal certificate.

Article 2 clause (1) of the LHPG states that "The products which enter, distributed, or sold in the Indonesian territory must have the halal certification." This means the issuing of the Governmental Decree No. 31 of 2019 on the Halal Product Certification, which states that "All products, both goods and services which are distributed in the Indonesian territory must have the halal certification." Because of that, the implementation of the Governmental Decree No. 31 of 2019 shows that the halal certification is an obligation. The halal certification is the acknowledgement of the halalness of a product which is issued by the Halal Product Guarantee Governing Body based on a written fatwa issued by the Indonesian Islamic Scholar Assembly.

\section{References}

1. The Indonesian Ministry of National Development Plan. Masterplan of the Indonesian Sharia Economy 2019-2024. Jakarta: Kementperbanas; 2018. p. 52.

2. Chusniatun, Absori, Dimyati K, et al. Legal protection for child criminals at the juvenile detention center: Study of psychiatric health. J Global Pharma Technol. 2020;12(2):91-5.

3. Waluyo B. The Law Enforcement in Indonesia. Jakarta: Sinar Grafika; 2016.

4. Soekanto S. The Indonesian Customary Law. Jakarta: Rajawali Press; 2008

5. Soekanto S. A Legal-sociological Analysis on Social Problems. Bandung: Alumni; 1989.

6. Abdullah M, Soekanto S. The Law of Sociology in the Society Jakarta: Rajawali Press; 1987.

7. Budiono A, Absori, Harun, Nugroho HS, Dimyati K. The ideal management of health insurance for Indonesia according constitution. Calitatea. 2020;21(176):48-50.

8. Rahardjo S. The Problems in Law Enforcement: A Sociological Analysis. Bandung: Sinar Baru; 1983.

9. Djumhana M. The Law on Consumer Protection in Indonesia. Bandung: Citra Aditya Bakti; 2003.

10. Safira M. The Indonesian Economic Law. Ponorogo: CV Nata Karya; 2015.

11. Sulaeman F. The Juridical Analysis on the Distribution of Chinese Products in Mecca which becomes Souvenirs of Pilgrimage Congregations from Indonesia Based on the Law no. 8 of 1999 on Consumer Protection. Bandung: Unpas; 2017.

12. Al-Fanjari A. The Value of Health in the Islamic Sharia. Jakarta: Bumi Aksara; 1996.

13. Hukum Online. Certified or Excluded by Imported Halal Product Available from: http://www.hukumonline.com. [Last accessed on 2019 Sep 15].

14. Charty M. Halal product guarantee in Indonesia. J Legislas Indones. 2017;14(1):100.

15. Waharini $F$, Purwantini $A$. The industrial development model of halal food in Indonesia. J Muqtasid. 2018;9(1):2. https://doi. org/10.18326/muqtasid.v9i1.1-13

16. Subekti T. The Legal Dictionary. Jakarta: Pradya Paramita; 1983.

17. Hukum Online. The Law on Halal Product Guarantee Gives Legal Certainty to Consumers. Available from: http://www. hukumonline.com. [Last accessed on 2019 Sep 12].

18. Hukum Online. Be Certified or Be Pushed Away by Hala Imported Products. Available from: http://www.hukumonline. com. [Last accessed on 2019 Sep 15].

19. Hasan K. The legal certainty of food product halal certification and labelling. J Dinamika Hukum. 2014;14(2):232.

20. Madjid N. National Culture, the Civil Society, and the Future of the Nation. Bandung: Pustaka Hidayah; 1999.

21. The Indonesian Ministry of Trade. Healthy Living with Hala Products. Jakarta: Warta Ekspor; 2015.

22. Yafie A, et al. The Fiqh of Free Trade. Jakarta: Teraju; 2004 